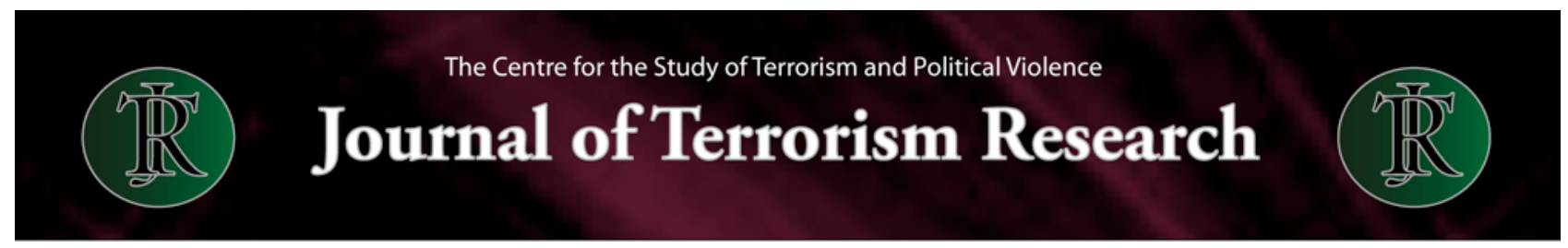

\title{
Lone Wolves in Cyberspace
}

\author{
by Gabriel Weimann
}

Keywords: Lone-wolf, Communication, Internet, Social media, Open-Source Jihad, al-Qaeda

\begin{abstract}
Lone-wolf terrorism has been regarded as a serious threat to public safety in recent years. Moreover, the phenomenon appears to be increasing at an alarming rate. However, the gap between the perceived threat of lone-wolf terrorism on the one hand and the almost exclusive scholarly focus on group-based terrorism on the other indicates the need for more conceptual and empirical examinations of lone-wolf terrorism. One perspective highlighted in this article is the use of online communication platforms. In nature, wolves do not hunt alone: they hunt in packs. As this study demonstrates, lone-wolf terrorists are not really alone. They are recruited, radicalized, taught, trained and directed by others. Analysis of all recent cases, reports and studies of these individual attackers reveals the importance to lone wolves of online platforms, ranging from websites to new social media (e.g., Facebook, Twitter, YouTube and more). After reviewing the role of these platforms for lone-wolf terrorists in general and for the "new" al-Qaeda, in particular, the paper concludes with proposed counter-terrorism measures applicable to this new arena.
\end{abstract}

\section{Introduction}

"The most likely scenario that we have to guard against right now ends up being more of a lone-wolf operation than a large, well-coordinated terrorist attack."

President Obama, August 16, 2011

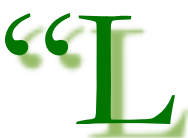

one-wolf terrorism is the fastest growing form kind of terrorism. Before 9/11, the men who went to terrorist camps and to Jihadi mosques where radical Imams preached jihad were seen as constituting the largest terror threat. Since 9/11, a gradual change has occurred. The real threat now comes from the single individual, the 'lone wolf', living next door, radicalized on the internet, and plotting strikes in the dark. A lone wolf is an individual or a small group of individuals who uses traditional terrorist tactics - including the targeting of civilians - to achieve explicitly political or ideological goals, but who acts without membership in, or cooperation with, an official or unofficial terrorist organization, cell, or group. The Unabomber, the Oklahoma City bomber, and the Fort Hood and Oslo attackers are examples of this new form of terrorism. Currently, less than two percent of terrorism in most countries that keep terrorism statistics can be attributed to lone-wolf terrorists but the problem is a rapidly growing one [1]. The report issued by the Institute for Safety, Security and Crisis Management on Terrorism (COT/TTSRL), which uses the RAND Terrorism Knowledge Base, reveals two trends: First, the number of lone-wolf attacks has increased in recent decades; second, lone wolves seem to come from all types of extremist ideological and religious groups [2]. 


\section{Journal of Terrorism Research}

Acts of lone-wolf terrorism have been reported in the United States, Germany, France, Spain, Italy, Canada, Australia, the Netherlands, Russia, Great Britain, Denmark, Portugal, Poland and Sweden. The fatal shooting in 2011 of two American airmen in Frankfurt by a Kosovar Albanian, the 2009 shooting rampage on the Fort Hood army base in Texas, or the 2011 deadly attack by the Norwegian right-wing extremist Anders Breivik killing 76 people in a bombing and shooting rampage - all share one thing in common: they were lone-wolf attacks. These lone wolves are challenging the police and intelligence community, as they are extremely difficult to detect and to defend against. Compared to group or network terrorism, lone wolves have a critical advantage -they more easily avoid identification and detection before and after their attacks since most of them do not reveal their inclinations, visions, and plans. However, as this paper will attempt to demonstrate, these lone terrorists are not completely divorced from contact with others. They connect, communicate and share information, know-how and guidance -- all online -- on the "Dark Web".

Following the Fort Hood shooting, Bruce Hoffman commented "I used to argue it was only terrorism if it were part of some identifiable, organized conspiracy..." but he was changing his definition because, "This new strategy of al-Qaeda is to empower and motivate individuals to commit acts of violence completely outside any terrorist chain of command."[3] Every month, Hoffman noted, there has been either a terrorist act committed or one broken up before it could be carried out. President Obama expressed unease at this trend. In a speech in August 2011 he argued that, "The biggest concern we have right now is not the launching of a major terrorist operation, although that risk is always there. The risk that we're especially concerned over right now is the lone-wolf terrorist, somebody with a single weapon being able to carry out wide-scale massacres of the sort that we saw in Norway recently."

Europol's recent annual report on terrorism and terrorist trends highlights the rise in lone-wolf attacks in Europe [4]. Rob Wainwright, director of Europol, summed up the situation like this: "Radicalization into violent extremism and lone-wolf attacks represents a significant threat for European citizens and have led to many tragedies. Looking ahead, lone actors will continue to pose a threat, whether inspired by political or religious extremism" [5]. However, despite the alarming increase in lone-wolf terrorism, there seems to be a gap between the perceived threat of lone-wolf terrorism, on the one hand, and the almost exclusive scholarly focus on group-based terrorism, on the other hand. The need for more conceptual and empirical examinations of lone-wolf terrorism may lead, as this study suggests, to revealing the lone-wolves' reliance on modern communication platforms. The analysis is based on a database collected in a 14-year-long project of monitoring thousands of terrorist websites and online forums, chatrooms and social networking. When this research was started in the late 1990s, there were merely a dozen terrorist websites; by 2000 , virtually all terrorist groups had established their presence on the Internet and in 2003 there were over 2,600 terrorist websites. The number rose dramatically and by January 2012 the archive contains almost 8,000 websites serving terrorists and their supporters. The monitoring of terrorist online platforms involves tracking them, downloading their contents, translating the messages (texts and graphics) and archiving them according to a preset coding system [6]. Given the rather broad application of the lone wolf's definition, this paper will focus on the most frequent form today, the jihadist lone-wolf terrorism.

\section{Who are the lone wolves?}

The term "lone wolf" was popularized in the late 1990s by two white supremacists, Tom Metzger and Alex Curtis, as part of an effort at encouraging fellow racists to act alone in committing violent 


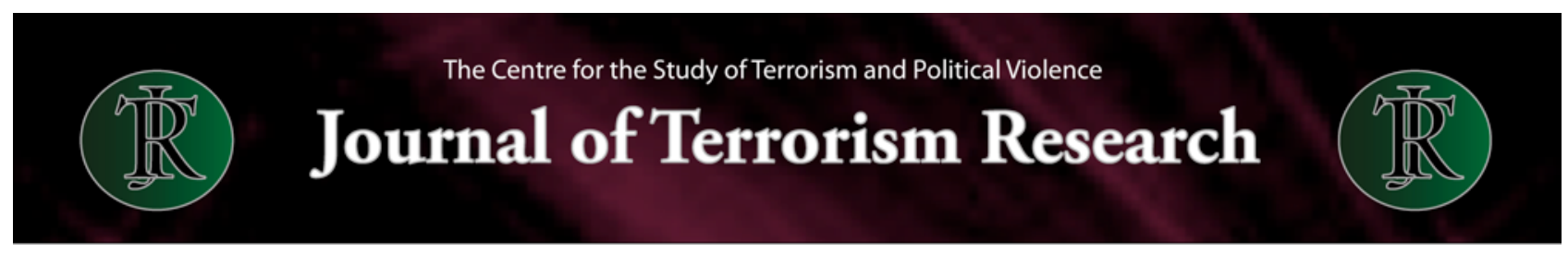

crimes for tactical reasons. Other terms that have been used to describe similar or comparable forms of political violence include "leaderless resistance" and "freelance terrorism."

A lone wolf is someone who commits violent acts in support of some group, movement or ideology, but does so alone, outside of any command structure. Lone- wolf terrorism is defined as follows: " [...] terrorist attacks carried out by persons who (a) operate individually, (b) do not belong to an organized terrorist group or network, and (c) whose modi operandi are conceived and directed by the individual without any direct outside command or hierarchy" [7]. This definition covers such Islamist lone wolves as Nidal Malik Hasan, the Fort Hood killer, Abdulhakim Mujahid Muhammad, who opened fire on a U.S. military recruiting office in Little Rock, Arkansas, as well as anti-Semitic devotees like Buford Furrow, who attacked a Jewish Community Center, and Eric Rudolph, also known as the Olympic Park Bomber, who perpetrated a series of bombings across the southern United States between 1996 and 1998 that killed two people and injured at least 150 others.

Usually, the lone-wolf terrorist shares an ideological or philosophical identification with an extremist group, but does not communicate with that group. While the lone wolf's actions are motivated to advance a certain group's goal, the tactics and methods are conceived and directed solely by the individual, without any outside command or direction. . Because of this lack of any personal contact with a larger group, lone-wolf terrorism poses a particular problem for counterterrorism officials, for it is considerably more difficult to gather intelligence on lone-wolves than on conventional terrorists. In their paper entitled, "Lone Wolves; How to Prevent This Seemingly New Phenomenon," Bakker and de Graaf examined the rise in lone-wolf terrorism and its characteristics and reached this conclusion: "There is no single, standardized profile of a lone wolf. Nonetheless, it is possible to distinguish between different categories of lone-wolf terrorists based on their ideological or religious background" [8]. A more promising way to analyze lone wolves is by applying a systematic typology or categorization of these highly variegated individuals.

\section{Typology of Lone Wolves}

An analysis of lone-wolf terrorism distinguishes various categorizations of this complex phenomenon. The first distinction is between two forms, chaos and career [9]. Chaos lone-wolf terrorism involves a single event, which is singularly disruptive. Suicide bombing is a major form of chaos lone-wolf terrorism. A single event is planned and conducted in such a manner that maximum impact in terms of casualties and/or public visibility is achieved. The The Fort Hood Massacre by Major Nidal Hasan is an example of chaos terrorism by a lone wolf and so is the case of Andres Breivik, the Norwegian mass murderer and terrorist. On 22 July 2011, Breivik bombed the government buildings in Oslo, which resulted in eight deaths. He then carried out a mass shooting at a camp of the Workers' Youth League (AUF) of the Labor Party on the island of Utøya where he killed 69 people, mostly teenagers.

Career or serial terrorism by a lone-wolf operative usually involves a continuous series of lowerlevel acts of violence over an extended period of time. Ted Zazinsky, the so-called Unabomber, is an example of a career lone-wolf terrorist. Kazinsky engaged in a mail-bombing campaign that spanned almost 20 years and killed three people while injuring more than two dozen others. Lonewolf terrorists who engage in career or serial terrorism see their violent actions as a long-term strategy, in which survival is a prerequisite for the continued visibility and viability of their campaign.

Another distinction relates to the type of individual terrorist. Phillips and Pohl applied economic models to develop a profile of lone-wolf terrorists. Specifically, they noted that an "important 


\section{Journal of Terrorism Research}

advantage of the rational choice approach to offender profiling is its capability at handling cognitive and behavioral factors as well as situational factors" [10]. Based on a rational choice model, they identified two basic types of lone-wolf terrorists, the risk-aversive and the risk-seeking individual. The risk- aversive lone-wolf terrorist is a "part-time" terrorist who engages in low-level acts of serial terrorism while also engaging in other, more legitimate forms of activism. In contrast, riskseeking lone wolves employ an alternative calculus, placing higher value on the expected marginal return of their acts in comparison to the potential threat of exposure and capture. For this latter personality, in essence, the risk is of as much importance, and possibly more so, than the cause or crusade.

Pantucci offered still another typology of the lone wolves, based on the means and context of selfradicalization, their tactics of engagement and the framework of available support [11]. He classified them into offers four categories: Loner, Lone Wolf, Lone Wolf Pack, and Lone Attacker. The Loner is defined as an individual who plans or attempts to carry out an act of terrorism using the cover of extreme ideology. However, while he (or she) may exploit an ideology to provide an explanation for their action, Loner terrorists do not appear to have any actual connection or contact with extremists - beyond their ability to access such groups or individuals through passive consumption, whether of the internet or from society at large.

Lone Wolves, Pantucci, are individuals who, while appearing to carry out their actions alone and without any physical instigation from the outside, in fact demonstrate some level of contact with operational extremists. Close analysis demonstrates that while similar to Loners, in that they act alone when operating in the real world (as opposed to the online world), Lone Wolves have some level of contact with members of a terrorist organization; furthermore, they possibly make contact with such individuals through the internet in what can appear to be some sort of command and control structure.

The Lone Wolf Pack category resembles that of the Lone Wolves, with one exception: rather than there being a single, ideologically motivated individual, it is a group of individuals who selfradicalize. This subset is in many ways the definition of Sageman's "bunch of guys" theory, according to which groups form, radicalize and then seek to join the jihad. As Sageman describes the process, "social affiliation with the jihad accomplished through friendship, kinship and disciplineship; progressive intensification of beliefs and faith leading to acceptance of the global Salafi Jihadi ideology; and formal acceptance to the jihad through the encounter of a link to the jihad" [12]. What distinguishes this group from the broader community of terrorists is that they have not taken the final step of making contact with operational extremists or, if they have, it is not done in a way to further immediate operational goals.

Pantucci's final group is that of the Lone Attackers - these are individuals who operate alone but demonstrate clear command and control links with a terrorist group or affiliated groups. Unlike the Lone Wolves or Lone Wolf Packs, individuals classified as Lone Attackers have contact with active extremists, rather than loose online connections or aspirational contacts. In other words, they are in fact simply one-man terror cells dispatched by terror groups.

Despite the differences among these categories, they display a clear communality: lone wolves are not really alone. They are linked, networked or communicated with through the Internet.

\section{The Role of the Internet}

In nature, wolves do not hunt alone: they hunt in packs. So, too, with the lone-wolf terrorists: there is a virtual pack, a social network, behind them. They may operate alone, but they are recruited, 


\section{The Centre for the Study of Terrorism and Political Violence \\ Journal of Terrorism Research}

radicalized, taught, trained and directed by others. They seem to be alone and yet there are social ties linking them to others as a report released by the Combating Terrorism Center at West Point concludes:

An assessment of eighty terrorist incidents both successful and failed during a seventeen-year period from 1993 to 2010 using the strict definition of a lone wolf attack developed above is instructive...Many of these forty-five individuals in fact received training abroad or joined larger organizations at some point in their radicalization process [13].

What is the role of the Internet as an incubator or accelerator of the Lone Wolf phenomenon? Pantucci's conclusion in this regard is instructive:

The internet is clearly the running theme between most of the plots included in this dataset [on lone wolves] and it appears to be a very effective tool: it provides a locus in which they can obtain radicalizing material, training manuals and videos. It provides them with direct access to a community of like-minded individuals around the world with whom they can connect and in some cases can provide them with further instigation and direction to carry out activities. Many of the individuals in the dataset demonstrate some level of social alienation - within this context, the community provided by the internet can act as a replacement social environment that they are unable to locate in the real world around them [14].

A report by the General Intelligence and Security Service in the Netherlands (AIVD) came to a similar conclusion:

The AIVD is aware of the fact that lone wolves often plot and carry out a (violent) act on their own, but has found that they rarely radicalize in complete isolation....The AIVD argues that radicalization is a social phenomenon. This also applies to most lone wolves. In the aftermath of such events, it is often discovered that lone wolves hardly had any contact with like-minded individuals in real life, but did maintain active contact with people on the Internet. In retrospect, it is then concluded that these contacts, as well as the consumption of jihadist propaganda and the online discourse, have contributed to their radicalization and (may also) have inspired them to commit such a (violent) act [15].

An intelligence report by the Canadian government's Integrated Threat Assessment Centre also expressed concern about the emerging threat posed by lone-wolf Islamist terrorists. The report stressed the importance of the Internet:

The Internet is helpful to an individual who may be preparing to conduct a lone-wolf attack, providing ideological motivation, encouragement, and justification, all within an anonymous 


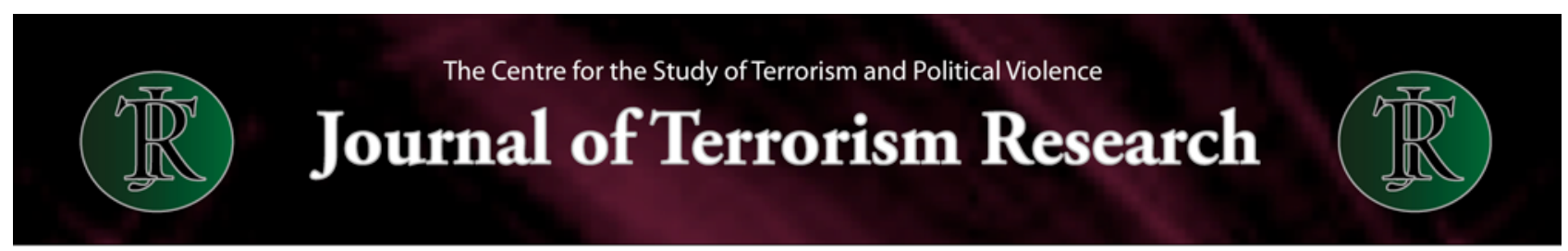

environment....Islamist extremist web sites offer not only theoretical and religious instruction

but also practical on-line training courses that urge visitors to take action on their own. For

example, the comprehensive Encyclopaedia of Preparation for Jihad is available online.

Professional, video-formatted instructional materials detailing various explosive

manufacturing recipes have also begun to circulate widely on the web in the past two years,

along with at least 22 other separate audio-visual terrorist manuals [16].

Europol's most recent annual terrorism situation and trend report, published in April 2012, highlighted the importance of the internet. The report states that the internet has become the "principal means of communication" for extremist groups, which now have a "substantial online presence." As well as its use for propaganda, recruitment, fundraising and planning - facilitated by social media - the internet also has the potential to be employed in cyber-attacks on the operating systems of vital infrastructure in EU member states [17].

A recent example may illustrate the online process. In 2011, Jose Pimentel was arrested for planning attacks with home-made pipe bombs against police vehicles and postal facilities in New York and New Jersey. Pimentel, a native of the Dominican Republic who had come to the U.S. at the age of 8, was an unemployed, 27-year-old Muslim convert and al- Qaeda sympathizer who lived in Manhattan. He was charged with five counts of building pipe bombs targeting returning veterans from Iraq and Afghanistan. Pimentel was not part of any known al-Qaeda organization. However, the inspiration for his planned bombing attacks came from reading instructions in the online Inspire Magazine produced by al-Qaeda and the American-born cleric Sheik Anwar al-Awlaki on the Arabian Peninsula. According to New York authorities, Pimentel was not just radicalized by the alQaeda magazine, but he also found in its pages the instructions he used to build the pipe bombs; this was thanks to a notorious article in English, entitled, "How to make a bomb in the kitchen of your mom."

Reading Inspire magazine was not Pimentel's main online activity. He maintained a massive website on Blogger and a YouTube channel featuring hundreds of radical works. As an analysis of Pimentel's online footprints reveals, he was "directly linked online to known extremists through whom he is connected to some hundreds of like-minded individuals." [18] Pimentel's website, TrueIslam1.com, hosted an impressive archive of jihadist texts, with audio and video organized by means of the online publishing tool Blogger. The website connects to Pimentel's YouTube channel, which was similarly thorough; it had collected more than 600 videos relating to radical and violent interpretations of Islam, 60 of which he had uploaded himself. This channel had more than 1,500 subscribers.

\section{Al-Qaeda calls for lone wolves}

One of the most difficult challenges faced by al-Qaeda today is the on-going loss of a large part of its first-, second- and even third-generation leadership, some of whom have been assassinated, others arrested, while still others have dissociated themselves from the organization and its terrorist methods. As observed in Europol's recent report, "As a consequence of sustained military pressure, al-Qaeda core have publicly discouraged sympathizers from travelling to conflict zones in order to join them. It has instead promoted the idea of individually planned and executed attacks in Western countries without the active assistance of any larger organization" [19]. 


\section{Journal of Terrorism Research}

Partly out of necessity, al-Qaeda has now thrown its weight fully behind "lone" terrorism. Already in 2003, an article was published on an extremist internet forum called Sada al Jihad (Echoes of Jihad), in which Osama bin Laden sympathizers were encouraged to take action without waiting for instructions. In 2006, a text authored by an al-Qaeda member, Abu Jihad al-Masri, "How to fight alone," circulated widely in jihadist fora. Another prominent Salafi writer, Abu Musab al-Suri, also advocated that acts of terrorism be carried out by small, autonomous cells or individuals. $\mathrm{He}$ outlined a strategy for global conflict that took the form of resistance by small cells or individuals and kept organizational links to an absolute minimum.

In March 2010, As-Sahab, al-Qaeda's media wing, released an English-language video entitled, “A Call to Arms," and featuring an American-born spokesperson, Adam Gadahn. The video, directed at jihadists in the United States, Israel, and the United Kingdom, highlights the Fort Hood shooter, Nidal Hasan, whom Gadahn describes in glowing terms ("a pioneer, a trailblazer and a role model who has opened a door, lit a path, and shown the way forward for every Muslim who finds himself among the unbelievers..."). Nidal Hasan is held up as an exemplary figure for his loyalty to Islam and Muslims in defiance of his unbeliever commanders and for having struck at a sensitive target in the heart of America. Gadahn then uses the example of Nidal Hasan to call on other Muslims in the "Crusader West," especially in the U.S., Britain, and Israel, to undertake lone-wolf attacks. He advises his listeners to focus in particular on targets that will do serious economic damage to these countries, and points to the $9 / 11$ attacks to show that such attacks need not necessarily employ conventional firearms.

In an early June 2011 English-language video message, headlined, "Do Not Rely on Others, Take the Task upon Yourself," Gadahn even more clearly emphasizes lone-wolf operations. He suggests possible measures: "Let's take America as an example. America is absolutely awash with easily obtainable firearms. You can go down to a gun show at the local convention center and come away with a fully automatic assault rifle, without a background check, and most likely without having to show an identification card. So what are you waiting for?" [20].

On February 10, 2012, a member of the Shumoukh al-Islam jihadi forum, "Abu Asma' AlCubi" ("the Cuban"), posted a message detailing how Muslims living in the West, particularly in the U.S., can promote the global Jihadi movement and can weaken America from within. Al-Cubi writes that it has become clear to all that the two main forces operating in the geopolitical and ideological arenas are al-Qaeda and its supporters, on the one hand, and the U.S. and its allies, on the other. Referring to al-Qaeda as a "hidden phenomenon," he says that the organization has proven itself to be the force that is the stronger and more united of the two, especially after it defeated the Americans and their allies in Afghanistan and Iraq.

Al-Qaeda in the Arabian Peninsula (AQAP), an al-Qaeda affiliate, has been especially vocal in encouraging lone acts of terrorism. Its online English-language magazine Inspire promotes "opensource jihad," a new tactic that emerged as the al-Qaeda leadership steadily vanished in the decade following 9/11. With its leaders either dead or in jail, al-Qaeda had to apply new modes of attack. The organization splintered first into "franchises" by country or region, then further into lone operators. Inspire became an important tool for recruiting, informing and motivating these lone jihadists. Each edition of the magazine, in fact, has a special section called, "Open Source Jihad," which is intended to equip aspiring jihadist attackers with the tools they need to conduct attacks without traveling to jihadist training camps. It is also dedicated to helping terrorist sympathizers in the West carry out attacks by including, among other things - as was seen above in the case of Jose Pimentel-bomb-making recipes. Inspire has featured articles attributed to three prominent violent jihadist propagandists with strong American ties: Gadahn, the radical U.S.-born imam Anwar al- 


\section{Journal of Terrorism Research}

Awlaki, and the Saudi-born American citizen Samir Khan. The latter two were killed in a U.S. air strike in Yemen in September 2011.

The article, "How to Make a Bomb in Your Mom's Kitchen," mentioned earlier, was downloaded by individuals who plotted terrorist attacks in both the U.S. and the UK (e.g., Naser Jason Abdo, a Muslim U.S. soldier who allegedly plotted to attack the Fort Hood military base, and Pimentel, who had started making a pipe bomb based on the recipe when he was arrested). The magazine has also heavily featured the writings of a Syrian al-Qaeda-linked terrorist, Abu Musab al-Suri, who pioneered the concept of individual terrorism before the 9/11 attacks. "We ask the Muslim youth to be a terrorist. Why do we ask for such individual terrorism? First because secret hierarchical organizations failed to attract Muslims," al-Suri told recruits in Afghanistan in 2000, according to a videotape obtained by CNN [21]. The articles in Inspire clearly promote individual jihad; thus, the Fall 2010 edition editorialized: "Spontaneous operations performed by individuals and cells here and there over the whole world, without connections between them, have put the local and international intelligence apparatus in a state of confusion, as arresting the members of aborted cells does not influence the operational activities of others who are not connected with them." The ideas and methods for terror attacks are meant for anyone, including those without direct ties to al-Qaeda or its affiliates. Thus, the Summer 2010 issue advised making a pipe bomb using everyday materials, the Fall 2010 issue encouraged using one's car to "mow down" people in crowded places and the Winter 2010 issue discussed how to blow up buildings.

Since its foundation, Inspire magazine has also advocated the concept that jihadists living in the West should conduct attacks there, rather than traveling to places like Pakistan, Somalia or Yemen, since such travel might bring them to the attention of the authorities. Indeed, Inspire views attacking in the West as "striking at the heart of the unbelievers." The October 2010 issue included an article, entitled "Tips for Our Brothers in the United States of America," that contained this recommendation: "We strongly encourage our brothers to fight jihad on US soil.... A random shooting rampage at a crowded restaurant in Washington D.C. at lunch hour, for example, might end up knocking out a few government employees [and it] would attract additional media attention." Gaining world attention has always been important for al-Qaida.

On May 2, 2012, The eighth and ninth issues of Inspire were released on jihadist forums. Both editions reinforce al-Qaida's promotion of lone-wolf attacks, but each issue presents different arguments and directions. The eighth issue, carrying the cover headline, "Targeting Dar al-Harb Populations," advocates the lone-wolf trend for non-Muslim lands in the same way as did previous editions. It details plans for new attack methods in the "Open Source Jihad" section, and presents the culmination of Anwar al-Awlaki's justification for killing American civilians. This issue also explains to potential lone wolves how to use small handguns and to build remote-controlled detonators for explosives. The contents of the eighth issue clearly rely on articles from previous issues.

The ninth issue, entitled "Winning on the Ground," includes instructions for individuals wishing to carry out lone-wolf jihad attacks. An article entitled, "The Convoy of Martyrs: Rise Up and Board with Us," declares,

The objective of this workshop is to communicate with those seek[ing] martyrdom operations, or those who want to execute a slaughter to the enemies of Islam, [or] those who have no means of contacting their mujahideen brothers. Whatever the reason, the aim is to activate them in the midst of the enemy, weather [sic] the enemy is the Jews, the Christians or the apostates. It is becoming obvious to many that the concept of individual jihad, which [has] begun to appear recently, has been called for by the leaders of jihad. 


\section{Journal of Terrorism Research}

The article instructs candidates to send basic information about themselves to AQAP's "military committee," which will then help them in planning and executing the attack; it will also take responsibility for the incident and provide media coverage. The article includes a list of conditions that candidates must meet a list of possible targets, and directions for contacting the committee securely by using encrypted emails. The ninth issue encourages individuals to act alone in gathering information, preparing and ultimately executing an attack. While the focus is still on individual jihad, the article does argue, however, that there must be an operational leadership, which AQAP will provide. This issue of Inspire also It places strong emphasis on lone-wolf operations to limit the opportunity for law enforcement interdiction, and advises small group plots only if the individual completely trusts his associates. The article, "Convoy of Martyrs," describes the qualifications of the desired lone wolf. According to the article, you must be a Muslim; must possess "maturity"; and be skilled in "listening and obeying." The terrorist group provides a public encryption key and a handful of Gmail, Yahoo and Hotmail accounts where you can send your idea about whom or what you would like to attack. If you are approved, you are sent to act, unencumbered by any traditional terrorist cell: "The only connection that mujahid has", states the text, "is with the group leadership. In this case it will be our military committee".

Another article in Inspire 9, "Qualities of an Urban Assassin," published by 'Uthman ibn Al-Ightiyal ("the son of assassination") described the necessary attributes and precautions of the would-be lone wolf operative. It discussed the need for inconspicuousness and integration into one's Western surroundings, with an emphasis on the set of knowledge and skills, including technological proficiency that would enable the individual fighter to properly plan and execute attacks in the heart of urban population centers. Al-Ightiyal called on the lone wolves not to limit their attacks to military or political targets, but to include "anyone that the shari'a allows him to eliminate," including "non-combatants."

There is convincing evidence on the impact of Inspire magazine among lone wolves. A growing number of lone-wolves were found to be linked with this online magazine, including Jose Pimentel, Naser Jason Abdo, Hakan Ertarkan, arrested in London on April 12, 2011 and found to be in possession of a CD issue of Inspire, The Germans Christian Emde and Robert Baum, arrested July 15, 201, when they tried to enter Britain in possession of electronic copes of Inspire, Zahid Iqbal, Mohammed Sharfaraz Ahmed, Umar Arshad, and Syed Farhan Hussain, arrested in Britain on April 24, 2012 and accused of working to recruit others, of taking their lead from Inspire, and of possessing copies of it.

\section{Social Media and Lone Wolves}

Online social networking platforms have become a powerful terrorist apparatus for attracting potential members and followers [22]. These types of virtual communities are growing increasingly popular all over the world, especially among younger demographics. Jihadist terrorist groups are especially targeting youths for propaganda, incitement and recruitment purposes. Accordingly, terrorist groups and their sympathizers are more and more exploiting predominately Western online communities, such as Facebook, MySpace and Second Life and their Arabic equivalents, to export their message. Anthony Bergin, a counter-terrorism expert, says that terrorists use these youthdominated websites as recruitment tools "in the same way a paedophile might look at those sites to potentially groom would-be victims" [23].

The "Forum on the Role of the Internet in Fighting Terrorism and Extremism" held in Saudi Arabia in January 2011 focused on the way the new, online social media has contributed to the increase in "lone wolf" acts. Marc Sageman, for example, argued that the internet has allowed "a conversation 


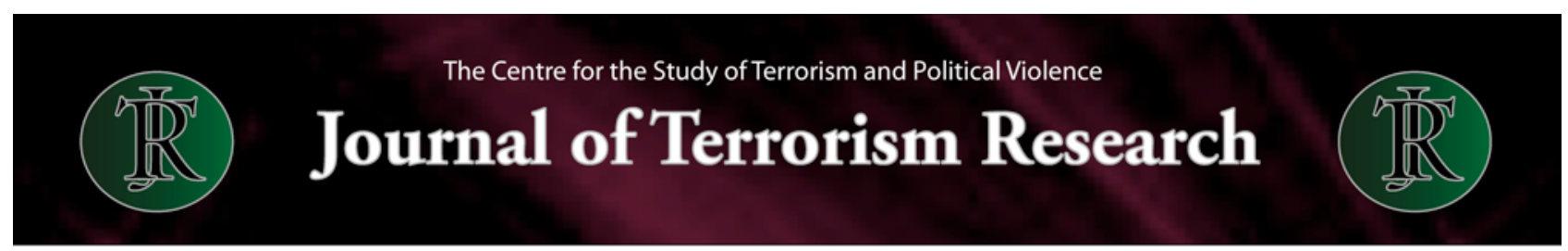

between disconnected, scattered people which was not possible before. This is because individuals shy about discussing their extremist views in person can easily find like-minded people on the web through chat rooms and forums. Through these virtual contacts, individuals gain enough confidence to carry out violent acts" [24]. Europol's annual terrorism situation and trend report of 2012 concluded:

\section{Online social media sites attract high numbers of users. Internet forums are an effective} means to address targeted audiences, including supporters who have no off-line links to terrorist organizations. Most forums restrict access, wholly or partially, to vetted members who need to prove their credentials and loyalty, or be recommended by established members before admission. Forum members are strongly advised by their moderators to use encryption software for direct communication [25].

The accused Fort Hood shooter, Nidal Hasan, exchanged internet messages with Awlaki, while the Frankfurt terrorist, Uka, was a Facebook friend with a number of known Islamist extremists in Germany. In fact, almost all of the lone-wolf cases in recent years have involved the use of electronic social media. For lone wolves, online communication provides the needed social bonding, a (virtual) community and a source of guidance, support and moral backing. Today, the internet allows anyone to post his or her ideology on the Web. James von Brunn, the Holocaust Museum shooter, operated an anti-Semitic web page, called the Holy Western Empire. Major Nidal Malik Hassan developed a Power Point presentation entitled, "The Koranic World View as it Relates to Muslims in the U.S. Military."

Terrorists harness the interactive capabilities of chatrooms, instant messenger, blogs, video sharingwebsites, self-determined online communities and social networks: "Today, $90 \%$ of terrorist activity on the internet takes place using social networking tools, be it independent bulletin boards, Paltalk, or Yahoo! eGroups. These forums act as a virtual firewall to help safeguard the identities of those who participate, and they offer subscribers a chance to make direct contact with terrorist representatives, to ask questions and even to contribute and help out the cyber jihad" [26]. The Jihadi forum Shumukh al-Islam is often used to exchange messages regarding lone-wolf attacks. Thus, for example, a prominent jihadist writer, Abu Asma'a al-Kubi, posted a message on February 9, 2012, on the Shumukh al-Islam forum, and in it he argued that attacks in the enemies' own lands will complement the actions of al-Qaeda abroad and expressed discontent with Muslims living in the West, questioning why they have not yet committed individual acts of jihad, especially after the killing Usama bin Laden, Anwar al-Awlaki, and Attiya Allah. In April 2012, a posting on this forum suggested that prospective lone-wolf fighters collaborate with al-Qaeda in the Arabian Peninsula (AQAP) and carry out attacks similar to the March 2004 Madrid train bombings. The suggestion came in response to a previous posting calling to avenge the death of former al-Qaeda leader Usama bin Laden. In that initial posting, the author had recommended that lone-wolves in Western countries use explosives to derail trains. Following up on that idea, he posted that a mass-casualty incident like the Madrid bombings will serve al-Qaeda's cause more than killing one average person. The jihadist wrote: "My beloved brother... the issue is not just to kill and that is it; rather, the issue is of changing the balance of power... Look to the Madrid operation. Three or four people were able to kill 191 people and cause the withdrawal of the Spanish army from Iraq" [27].

Hamas has also noted the power of social media. "We call for adopting a strategy on the basis of resistance and the upholding of our rights and constants," a Hamas spokesman, Sami Abu Zuhri, 


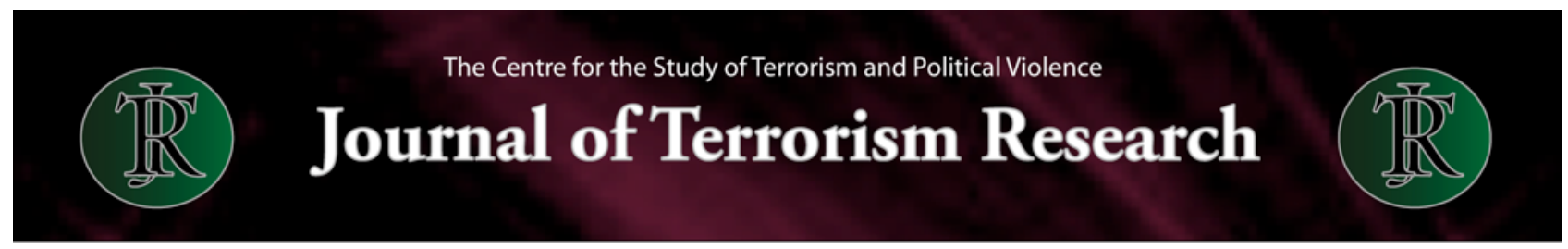

stated in an official message on Twitter. While statements in support of "resistance" may be oldfashioned, Hamas' leadership is capitalizing on the social media craze in order to reach a new crowd. Its new media push includes accounts on Youtube, Flickr, Twitter, and Facebook, as well as a website (www.hamasinfo.net) and forums. One such forum, run by the Ezzedeen al-Qassam Brigades, provides an official outlet for discussion, multimedia and advocacy on Hamas' behalf. It includes photos of "martyrdom operations" and videos honouring suicide attackers. Similarly, Hezbollah has established a vast network of operatives throughout Latin America and North America that could be used to wage terrorist attacks if directed to do so. More than 80 Hezbollah operatives have been identified in at least a dozen South American countries, according to Roger Noriega, former U.S. Assistant Secretary of State for Western Hemisphere Affairs [28].

In May 2012, a jihadist, urging fellow forum members to participate in a "workshop" to spread the Inspire e-magazine to Facebook, listed hundreds of links to American Facebook pages and groups where forum members could promote the publication. To assist in the campaign, which was highlighted with a promotional banner and given a prominent position on the Shumukh al-Islam forum, the author posted an example of a code that participants could use as a template to easily disseminate download links for the eighth and ninth issues of Inspire.

On March 22, 2012, several Jewish schoolchildren and a Rabbi were murdered by 23 year-old Mohamed Merah in Toulouse, France. Before he was shot dead by a police sniper, Merah said that he had videotaped this killing as well as the previous murder of three French soldiers. The terrorist had used a GoPro camera strapped to his chest to record the killing of his seven victims and then posted the gruesome footage online while he was in his flat surrounded by police. After his death, members of several online jihadist forums praised Merah for his attacks on French Jews and on soldiers. Postings on such forums have included calls for similar lone-wolf attacks and described Merah's shootings as Allah's revenge on France for its foreign policy and attitude toward Muslims. Later, a video tribute to Merah called, "The Lone Lion," began circulating on the forums. The video begins with text commending Merah for killing "three French soldiers returning from Afghanistan" and "a Jewish rabbi and his children." It also applauds him for fighting "the French special forces with courage until he was killed as a martyr." The video includes recordings of Osama bin Laden speaking about a promised war "between us and the Jews" and of current al-Qaeda leader, Ayman Al-Zawahiri, describing England and the United States as legitimate targets because of the civilian casualties in Iraq, Afghanistan and Gaza. A Facebook page, headlined "Homage to Mohamed Merah," that praised the lone killer was closed after France's interior ministry asked the social networking site to remove it. In the few hours it had been online, more than 500 people had consulted the Facebook page. Many of the visitors left comments attacking the police or supporting radical Islam.

\section{Conclusions}

Despite the many differences in background and tactics, lone wolves share some commonalities. One common characteristic is that they are not indeed so lonely: they are motivated, taught, recruited, incited or even trained by external sources; they display a degree of commitment to and identification with extremist movements; in other words, their solitary actions do not take place in a vacuum. These commonalities are important in identifying and understanding the process of radicalization [29]. The significant increase in lone-wolf terrorism in the past three decades can partly be explained by the adoption and use of various online platforms for the dissemination of lone- wolf tactics. Terrorist groups have learned how to appeal to potential lone wolves, to attract 


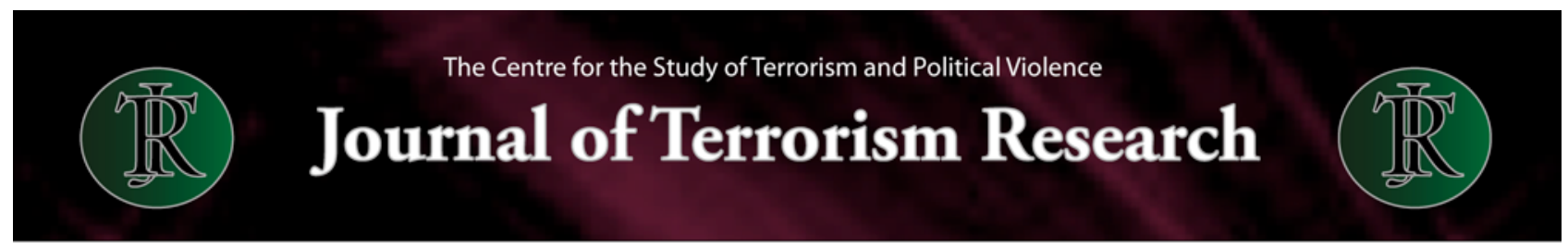

and seduce them, to train and teach them and finally to launch them on their attacks - all by using online communication, from forums and chatrooms to Facebook, YouTube and Twitter.

The alarming spread of lone-wolf attacks raises the issue of counter-terrorism (CT) measures. Attacks by lone operators provide the most challenging form of terrorism. Lone-wolf terrorists offer a nightmare for counterterrorism organizations, the police and intelligence communities, as they are extremely difficult to find, identify and arrest. However, the fact that lone wolves are not completely alone may lead to potential measures. First of all, according to Alex Shone of the Henry Jackson Society, the key factor concerning locating lone wolf attacks is knowing, not who will carry out an attack, but how such an attack is formulated (Shone, 2010). Shone stresses the need to study the radicalization processes of lone wolves. He shows that insight into these processes opens up possible avenues for effective CT measures to prevent or counter the threat of lone-wolf terrorism.

As Bakker and de Graaf conclude: "Knowing how lone operator attacks are formulated requires a far more sensitive detection system at the tactical, sharp-end of operations than most CT organizations currently use" [30]. Yet, if the process of recruiting, supporting and training lone wolves relies on online platforms, these sites can be monitored and studied. The "outreach" by law enforcement into radical, extremist, Jihadist and other terrorist communities is a key to providing early warnings of threats. Such warning signs include ties individuals may have developed with known radicals or online interaction through radical websites. Another CT measure to track down and find potential lone-wolf attackers is the use of online undercover agents and informants. For example, the New York Police Department has developed a Cyber Intelligence Unit, in which undercover "cyber agents" track the online activities of suspected violent extremists and interact with them online to gauge the potential threat they pose. The unit has played a key role in several recent terrorism investigations, including that of Abdel Hameed Shehadeh, who authorities allege attempted to travel overseas to Somalia to fight for the local al-Qaeda group.

An indication of the potential utility of these measures is the number of lone wolves that have been found to be in possession of terrorism material acquired by accessing online sources. The list includes, for example, Antonio Martinez, a Maryland man arrested for attempting to detonate a car bomb at a Maryland Army recruiting center in December 2010; Jason Naser Abdo, the soldier charged in a bomb plot targeting personnel at Fort Hood, Texas; Barry Walter Bujol, Jr., a Texas resident arrested for attempting to deliver money and other equipment to al-Qaeda in the Arabian Peninsula; and Mohamed Osman Mohamud, who was arrested in November 2010 for attempting to blow up a Christmas tree-lighting ceremony with a car bomb in Portland, Oregon. Mohamud went so far as to submit an article to AQAP's online English-language magazine, Inspire (it was not published), as well as to another online English-language terror magazine, called Jihad Recollections. These cases demonstrate not only the growing threat posed by individuals who selfradicalize without any physical interactions with established terrorist groups, but also their reliance on online communication, which may be used against them.

About the author: Gabriel Weimann is a Full Professor of Communication at the Department of Communication at Haifa University, Israel. His research interests include the study of political campaigns, persuasion and influence, modern terrorism and the media. He published seven books and more than 150 academic publications in scientific journals. His books include: Communicating Unreality (Los Angeles: Sage Publications, 2000); The Influentials: People Who Influence People (State University of New York Press, 1995); The Theater of Terror (New York: Longman, 1994); Terror on the Internet (Washington, DC: USIP Press, 2006); and Freedom and Terror (London: Routledge, 2011). He received numerous grants and awards from international foundations and was 


\section{The Centre for the Study of Terrorism and Political Violence Journal of Terrorism Research}

a Visiting Professor at various universities including University of Pennsylvania, Stanford University, Hofstra University, American University DC, University of Maryland, Lehigh University (USA), University of Mainz (Germany), Carleton University (Canada) and the National University of Singapore.

\section{Bibliography}

AIVD, General Intelligence and Security Service in the Netherlands (2012). Jihadism on the Web. A Breeding Ground for Jihad in the Modern Age, Amsterdam.

Bakker, E. and de Graaf, B. (2010). “Lone Wolves: How to Prevent This Phenomenon?” Paper presented at the expert meeting on "Lone Wolves", available at: http://icct.nl/userfiles/file/ICCT \%20EM\%20Lone \%20Wolves\%20Paper.pdf.

Bakker, E. and de Graaf, B. (2011). "Preventing Lone Wolf Terrorism: Some CT Approaches Addressed," Perspectives on Terrorism5; available at:

http://www.terrorismanalysts.com/pt/index.php/pot/issue/view/32.

Bates, R. (2012). "Dancing with Wolves: Today's Lone Wolf Terrorists," The Journal of Public and Professional Sociology 4(1); available at:

http://digitalcommons.kennesaw.edu/jpps/vol4/iss1/1.

Cole, M. (2011). "New Al-Qaeda Video: American Muslims Should Buy Guns, Start Shooting People," ABC News, June 3 ; available at http://abcnews.go.com/Blotter/al-qaeda-video-buyautomatic-weapons-start-shooting/story?id=13704264.

COT/TTSRL (2007), Lone-Wolf Terrorism. Case Study for Work Package 3: Citizens and Governance in a Knowledge-Based Society; available at:

http://www.transnationalterrorism.eu/tekst/publications/Lone-Wolf\%20Terrorism.pdf.

Cruickshank, P. and Lister, T. (2012). "The 'Lone Wolf'-The Unknowable Face of Terror." CNN, February 18 ; available at: http://articles.cnn.com/2012-02-18/opinion/opinion_lone-wolfterror 1 lone-wolf-terror-attack-lone-terrorists? $\mathrm{s}=\mathrm{PM}$ :OPINION.

EUROPOL (2012). Annual Terrorism Situation and Trend Report. European Police Office, April; available at: https://www.europol.europa.eu/sites/default/files/publications/europoltsat.pdf.

Gibbs, N. (2009). “The Fort Hood Killer: Terrified ... or Terrorist?” Time Magazine, November 11 ; available at: http://www.time.com/time/magazine/article/0,9171,1938698,00.html

Helfstein, S. (2012). Edges of Radicalization: Ideas, Individuals and Networks in Violent Extremism, a special report by the Combating Terrorism Center (CTC) at West Point.

Integrated Threat Assessment Center (Canada) (2007). "Lone Wolf Attacks: A Developing Islamist Extremist Strategy?" 29 June; available at:http://www.nefafoundation.org/miscellaneous/ FeaturedDocs/ITAC lonewolves_062007.pdf.

Internet Haganah (2012). "Jose-Pimentel, a-k-a Mohammad-Yusuf”; available at: http:// forum.internet-haganah.com/archive/index.php/t-358.html.

Kerbaj, T. (2008). "Facebook Terror Threat." The Australian, April 5; available at: http://www.theaustralian.com.au/news/facebook-terror-threat/story-e6frg6of-1111115980334. Masaon, D. (2012). “Europe Sees Rise in 'Lone Wolf' Terror Attacks.” Public Service Europe, April; available at: 


\section{Journal of Terrorism Research}

http://www.publicserviceeurope.com/article/1849/europe-sees-rise-in-lone-wolf-terrorattacks\#ixzz1tnGAB9FQ.

Murphy, C. (2011). "Terrorism Fight 'Must Shift to Cyberspace' Saudi Conference Agrees.” The National, January 27; available at: http://www.thenational.ae/news/world/middle-east/terrorismfight-must-shift-to-cyberspace-saudi-conference-agrees?pageCount $=0$.

Noriega, R. (2011). "Hezbollah in Latin America: Implications for U.S. Homeland Security." Written Testimony before a Hearing of the Subcommittee on Counterterrorism and Intelligence Committee on Homeland Security, U.S. House of Representatives, July 7 available at: http://homeland.house.gov/sites/homeland.house.gov/files/Testimony\%20Noriega.pdf.

Noguchi, Y. (2006). "Tracking Terrorists Online." Washingtonpost.com video report. 19 April; available at:

http://www.washingtonpost.com/wp-dyn/content/discussion/2006/04/11/DI2006041100626.html.

Pantucci, R. (2011). “Typology of Lone Wolves: Preliminary Analysis of Lone Islamist

Terrorists," Developments in Radicalisation and Political Violence. March; available at:

http://icsr.info/publications/papers/1302002992ICSRPaper_ATypologyofLoneWolves_Pantucci.pdf.

Phillips. P. and Pohl, G. (2011) "Economic Profiling: Can Economics Provide Behavioral Investigative Advice?" available at: http://ssm.com/abstract=1858975.

Sageman, M. (2004). Understanding Terror Networks. Philadelphia: University of Pennsylvania Press.

SITE, Monitoring Service (2012). "Jihadist Calls for Murder to Avenge Death of Usama bin Laden", available at: news.siteintelgroup.com/

Sone, A. 2010. “Countering Lone-Wolf Terrorism: Sustaining the CONTEST 'Vision.' Henry Jackson Society, May 17; available at:

http://www.henryjacksonsociety.org/stories.asp?id=1582.

Spaaij, R. (2010). The Enigma of Lone Wolf Terrorism: An Assessment, Studies in Conflict \& Terrorism, 33: 854-870.

Spaaij, R. (2010). The Enigma of Lone Wolf Terrorism: An Assessment. Studies

in Conflict \& Terrorism, 33: 854-870

Stewart, S. and Burton, F. (2008). "The Lone Wolf Disconnect.” January 30, Stratfor; available at: http://www.stratfor.com/weekly/lone_wolf_disconnect.

Weimann, G. (2006).Terror on the Internet: The New Arena, The New Challenges. Washington, DC: United States Institute of Peace Press.

Weiman, G. (2008). “WWW.Al-Qaeda: The Reliance of al-Qaeda on the Internet”, in Responses to Cyber Terrorism, NATO Science for Peace and Security Program. Amsterdam: IOS Press, pp. 61-69.

Weimann, G. (2010). “Terrorist Facebook: Terrorist and Online Social Networking.” In: Web Intelligence and Security (Eds., M. Last and A. Kandel), Amsterdam: NATO Science for Peace and Security Series, pp. 19-30.

Weimann, G. (2011). “Cyber-Fatwas and Terrorism”, Studies in Conflict and Terrorism, 34, 765-781. 


\section{The Centre for the Study of Terrorism and Political Violence \\ Journal of Terrorism Research}

\section{Notes:}

[1] Spaaij, R. (2010). The Enigma of Lone Wolf Terrorism: An Assessment. Studies

in Conflict \& Terrorism, 33: 854-870.

[2] COT/TTSRL (2007), Lone-Wolf Terrorism. Case Study for Work Package 3: Citizens and Governance in a Knowledge-Based Society; available at:

http://www.transnationalterrorism.eu/tekst/publications/Lone-Wolf\%20Terrorism.pdf.

[3] Cited by Gibbs, N. (2009). “The Fort Hood Killer: Terrified ... or Terrorist?” TIME Magazine, November 11 ; available at: http:// www.time.com/time/magazine/article/0,9171,1938698,00.html

[4]Europol (2012) Annual Terrorism Situation and Trend Report. European Police Office, April; available at: $\underline{\text { https:// }}$ www.europol.europa.eu/sites/default/files/publications/europoltsat.pdf

[5] Ibid. p. 1.

[6] Weimann, G. (2006).Terror on the Internet: The New Arena, The New Challenges. Washington, DC: United States Institute of Peace Press; Weimann, G. (2008).“WWW.Al-Qaeda: The Reliance of al-Qaeda on the Internet”, in Responses to Cyber Terrorism, NATO Science for Peace and Security Program. Amsterdam: IOS Press, pp. 61-69; Weimann, G. (2010). “Terrorist Facebook: Terrorist and Online Social Networking.” In: Web Intelligence and Security (Eds., M. Last and A. Kandel), Amsterdam: NATO Science for Peace and Security Series, pp. 19-30; Weimann, G. (2011). "Cyber-Fatwas and Terrorism”, Studies in Conflict and Terrorism, 34, 765-781.

[7] Spaaij, op cit, p.854-5.

[8] Bakker, E. and de Graaf, B. (2010). “Lone Wolves: How to Prevent This Phenomenon?” Paper presented at the expert meeting on "Lone Wolves", available at: http://icct.nl/userfiles/file/ICCT\%20EM\%20Lone\%20Wolves\%20Paper.pdf

[9] Bates, R. (2012). “Dancing with Wolves: Today's Lone Wolf Terrorists," The Journal of Public and Professional Sociology 4(1); available at:

http://digitalcommons.kennesaw.edu/jpps/vol4/iss1/1

[10] Phillips. P. and Pohl, G. (2011) "Economic Profiling: Can Economics Provide Behavioral

Investigative Advice?" available at: http://ssm.com/abstract=1858975, p. 1.

[11] Pantucci, R. (2011). “Typology of Lone Wolves: Preliminary Analysis of Lone Islamist

Terrorists," Developments in Radicalisation and Political Violence. Available at:

http://icsr.info/publications/papers/1302002992ICSRPaper_ATypologyofLoneWolves_Pantucci.pdf

[12] Sageman, M. (2004). Understanding Terror Networks. Philadelphia: University of

Pennsylvania Press, p. 183.

[13] Helfstein, S. (2012). Edges of Radicalization: Ideas, Individuals and Networks in Violent Extremism, a special report by the Combating Terrorism Center (CTC) at West Point.

[14] Pantucci, op cit, p. 34.

[15] AIVD, General Intelligence and Security Service in the Netherlands (2012). Jihadism on the Web. A Breeding Ground for Jihad in the Modern Age, Amsterdam, pp. 20-21.

[16] Integrated Threat Assessment Center (Canada) (2007). “Lone Wolf Attacks: A Developing Islamist Extremist Strategy?” 29 June; available at: http://www.nefafoundation.org/miscellaneous/FeaturedDocs/ITAC lonewolves 062007.pdf

[17] Masaon, D. (2012). “Europe Sees Rise in 'Lone Wolf' Terror Attacks.” Public Service Europe, April; available at: 


\section{The Centre for the Study of Terrorism and Political Violence Journal of Terrorism Research}

http://www.publicserviceeurope.com/article/1849/europe-sees-rise-in-lone-wolf-terror-attackstixzzltnGAB9FQ

[18] Internet Haganah (2012). “Jose-Pimentel, a-k-a Mohammad-Yusuf”; available at: http://forum.internet-haganah.com/archive/ index.php/t-358.html

[19] Europol, op cit, p. 17.

[20] Cited by Cole, M. (2011). “New Al-Qaeda Video: American Muslims Should Buy Guns, Start Shooting People,” June 3 ; available at http://abcnews.go.com/Blotter/al-qaeda-video-buy-automatic-weapons-start-shooting/story?id=13704264

[21] Cruickshank, P. and Lister, T. (2012). "The 'Lone Wolf'-The Unknowable Face of Terror." CNN, February 18 ; available at: http://articles.cnn.com/2012-02-18/opinion/opinion_lone-wolf-terror_1_lone-wolf-terror-attack-lone-terrorists?_s=PM:OPINION

[22] Weimann (2010), op cit.

[23] Quoted by Kerbaj, T. (2008). "Facebook Terror Threat." The Australian, April 5; available at: http://www.theaustralian.com.au/ news/facebook-terror-threat/story-e6frg6of-1111115980334

[24] Cited by Murphy, C. (2011). “Terrorism Fight 'Must Shift to Cyberspace' Saudi Conference Agrees.” The National, January 27; available at: http://www.thenational.ae/news/world/middle-east/terrorism-fight-must-shift-to-cyberspace-saudi-conference-agrees? pageCount $=0$

[25] Europol, op cit, p. 10.

[26] Evan Kohlmann, cited in Noguchi, Y. (2006). "Tracking Terrorists Online." Washingtonpost.com video report. 19 April; available at:

http://www.washingtonpost.com/wp-dyn/content/discussion/2006/04/11/DI2006041100626.html

[27] Cited by SITE, Monitoring Service (2012). "Jihadist Calls for Murder to Avenge Death of Usama bin Laden", available at: news.siteintelgroup.com/

[28] Noguchi, Y. (2006). "Tracking Terrorists Online." Washingtonpost.com video report. 19 April; available at:

http://www.washingtonpost.com/wp-dyn/content/discussion/2006/04/11/DI2006041100626.html

[29] COT/TTSRL, op cit, pp. 86-7.

[30] Bakker, E. and de Graaf, B. (2011). "Preventing Lone Wolf Terrorism: Some CT Approaches Addressed," Perspectives on Terrorism 5; available at:

http://www.terrorismanalysts.com/pt/index.php/pot/issue/view/32 